\title{
Manoeuvreren binnen smalle marges
}

Over de rol van wetgevingsjuristen bij de totstandkoming van wet- en regelgeving

\author{
Author(s) \\ Doornbos, Nienke; Mein, Arnt \\ DOI \\ 10.5553/RdW/138064242019040003003
}

Publication date

2019

Document Version

Final published version

Published in

Recht der Werkelijkheid

Link to publication

\section{Citation for published version (APA):}

Doornbos, N., \& Mein, A. (2019). Manoeuvreren binnen smalle marges: Over de rol van wetgevingsjuristen bij de totstandkoming van wet- en regelgeving. Recht der Werkelijkheid, 40(3), 30-50.

https://doi.org/10.5553/RdW/138064242019040003003

It is not permitted to download or to forward/distribute the text or part of it without the consent of the author(s) and/or copyright holder(s), other than for strictly personal, individual use, unless the work is under an open content license (like Creative Commons).

If you believe that digital publication of certain material infringes any of your rights or (privacy) interests,

please let the Library know, stating your reasons. In case of a legitimate complaint, the Library will make the material inaccessible and/or remove it from the website. Please contact the library:

https://www.amsterdamuas.com/library/contact/questions, or send a letter to: University Library (Library of the University of Amsterdam and Amsterdam University of Applied Sciences), Secretariat, Singel 425, 1012 WP Amsterdam, The Netherlands. You will be contacted as soon as possible. 


\title{
Manoeuvreren binnen smalle marges
}

\section{Over de rol van wetgevingsjuristen bij de totstandkoming van wet- en regelgeving ${ }^{*}$}

\author{
Nienke Doornbos \& Arnt Mein
}

\section{$1 \quad$ Inleiding}

\section{Zorgen over de rechtsstaat}

De afgelopen jaren zijn veelvuldig zorgen geuit over onze democratische rechtsstaat. In 2014 wezen Brenninkmeijer, voormalig Nationale ombudsman, en Tjeenk Willink, voormalig vicepresident van de Raad van State, op een spanning tussen democratie en rechtsstaat en benadrukten zij het belang van checks and balances en tegenspraak om rechtsstaat en democratie in evenwicht te houden. ${ }^{1}$ Meer in het bijzonder stelde Tjeenk Willink in dit verband dat 'het denken over het recht binnen de overheid is gemarginaliseerd en dat het recht door bestuur en politiek wordt gezien als beleidsinstrument'. ${ }^{2}$ Deze zorgen komen terug in jaarverslagen van de Raad van State over 2015 en 2018, waarin het belang van betrouwbare en bestendige wetgeving wordt benadrukt: 'Wetgeving is meer dan beleid in een ander jasje'3 en 'Het wetgevingsproces is geen "stempelmachine"' 4 De Raad van State waarschuwt voor het zuiver 'instrumenteel' gebruik van wetgeving om politieke en maatschappelijke akkoorden te vertalen of van een legitimatie te voorzien. Ook constateert het adviescollege dat 'vaak het primaat van de wetgever naar het bestuur [verschuift], waardoor de waarborg die de wet en het wetgevingsproces in de democratische rechtsstaat zouden moeten bieden, onder druk komt te staan'. 5

Van Lochem gaat in zijn proefschrift nog een stap verder en constateert dat er binnen de overheid soms zelfs openlijk in strijd met het recht wordt gehandeld, terwijl daar geen gerechtvaardigde redenen voor zijn. ${ }^{6}$ De rol van het recht wordt gerelativeerd. Van Lochem leidt die 'rechtsrelativering' onder meer af uit het feit dat overheidsjuristen in publicaties en interviews minder tegenwicht lijken te geven aan wetgeving die in juridisch opzicht problematisch is. Andere uitingsver-

* Wij danken Nick Huls, Rob van Gestel, Luc Verhey, Marijke ter Voert en de referenten van dit artikel voor hun zinvolle commentaar op eerdere versies.

1 Zij uitten deze kritiek tijdens een deskundigenbijeenkomst op 4 februari 2014 ter voorbereiding van het door de Eerste Kamer georganiseerde (eerste) debat over de Staat van de Rechtsstaat, Kamerstukken I 2013/14, 33750, VI, O. Zie ook Brenninkmeijer 2015.

2 Pagina 9 verslag deskundigenbijeenkomst.

3 Raad van State 2016, p. 18-21. Het belang van tegenspraak en een evenwicht van machten voor een goed functionerende democratische rechtsstaat komt ook terug in Tjeenk Willinks oproep Groter denken, kleiner doen (Tjeenk Willink 2019, p. 23-25).

4 Raad van State 2019, p. 32.

5 Raad van State 2019, p. 32.

6 Van Lochem 2012 en 2013. 
schijnselen zijn dat negatieve adviezen, bijvoorbeeld van de Raad van State, of een verstrekkende rechterlijke uitspraak, in toenemende mate als een te overkomen beletsel worden ervaren. Een ander voorbeeld is dat overheidsjuristen juridische bezwaren louter vatten in termen van een 'risicoanalyse', mede met het oog op toetsing door de rechter. De overschrijding van de rechtsnorm wordt alleen dan problematisch geacht als hiervan financiële of politiek ongewenste gevolgen zijn te vrezen, zoals een verplichting om tot schadevergoeding over te gaan of reputatieverlies.

\section{Rol van wetgevingsjuristen}

Bovengenoemde zorgen over de marginalisering en relativering van de betekenis van het recht binnen de overheid maakten ons nieuwsgierig naar de rol van wetgevingsjuristen bij de totstandkoming van wet- en regelgeving. Wetgevingsjuristen zijn immers gespecialiseerde overheidsjuristen, die hoofdzakelijk tot taak hebben om beleidswensen op verantwoorde wijze te vertalen in wet- en regelgeving. Zij verrichten hun werkzaamheden weliswaar onder verantwoordelijkheid van een bewindspersoon, maar als jurist hebben zij toch ook een eigen professionele verantwoordelijkheid om het recht en de beginselen die daaraan ten grondslag liggen te respecteren.

Indien juridische argumenten binnen de departementen minder gehoor vinden, zullen wetgevingsjuristen daar als eerste last van ondervinden, omdat het bij uitstek hun taak is om de juridische kwaliteit te waarborgen. Zij zullen wellicht loyaliteitsconflicten ervaren, vanwege hun dubbele professionele identiteit: als ambtenaar ligt hun loyaliteit bij de zittende bewindspersoon, als jurist ligt hun loyaliteit bij het recht en de rechtsstaat. ${ }^{7}$ Zolang de bewindspersoon recht en rechtsstatelijkheid hoog in het vaandel heeft, is er niet veel aan de hand. In het gros van de wetgevingstrajecten zullen zich wellicht geen loyaliteitsconflicten voordoen, omdat wetgevingsjuristen en beleidsambtenaren dezelfde publieke belangen voor ogen hebben of omdat het gaat om weinig omstreden of overwegend juridischtechnische wetsvoorstellen of aanpassingen van bestaand recht. Maar er zijn ook omvangrijke en controversiële wetgevingstrajecten, die maatschappelijk gevoelig liggen en waaraan veel juridische haken en ogen zitten. Loyaliteitsconflicten kunnen zich bijvoorbeeld voordoen als de bewindspersoon vernieuwingen nastreeft die op gespannen voet staan met hogere regelgeving, in het bijzonder grondrechten en algemene rechtsbeginselen.

Een voorbeeld biedt de op 1 augustus 2019 in werking getreden Wet Gedeeltelijk verbod gezichtsbedekkende kleding (in de volksmond het 'boerkaverbod' genoemd). ${ }^{8}$ Dit was een voor wetgevingsjuristen complex traject, omdat deze wet evident op gespannen voet staat met grondrechten van een minderheidsgroepering (de Raad van State heeft meerdere keren negatief geadviseerd over de voorstellen die aan deze wet ten grondslag lagen). Zeker als - zoals in deze casus -

7 Loth 2009; Van Lochem 2012 en 2013; Wierenga 2016.

8 Wet van 27 juni 2018, houdende instelling van een gedeeltelijk verbod op het dragen van gezichtsbedekkende kleding in het onderwijs, het openbaar vervoer, overheidsgebouwen en de zorg (Wet gedeeltelijk verbod gezichtsbedekkende kleding), Stb. 2018, 222. 
de publieke opinie zich roert, belangengroeperingen actief worden en rechtsgeleerden zich in vakbladen kritisch uitlaten, moet een wetgevingsjurist sterk in zijn of haar schoenen staan om geen speelbal te worden van uiteenlopende belangen. De positie en opstelling van de wetgevingsjurist doet er in onze ogen toe. Hij moet uiteindelijk de wetten of regels opstellen die de toets der kritiek (bijvoorbeeld van de Raad van State of de rechter) kunnen doorstaan. Zijn of haar handelingsruimte is echter beperkt, omdat hij hiërarchisch ondergeschikt is aan zijn bewindspersoon (en uiteraard ook aan zijn directe leidinggevenden) en omdat hij slechts een radertje is binnen een groot ambtenarenapparaat. Hoeveel ruimte heeft een wetgevingsjurist dan om tegenwicht te bieden tegen voorstellen als daar juridische of rechtsstatelijke bezwaren aan kleven? Het valt te verwachten dat de loyaliteit van een wetgevingsjurist uiteindelijk bij zijn bewindspersoon ligt. Uit eerder onderzoek blijkt dat ook het geval te zijn en dat is onzes inziens ook wel begrijpelijk. ${ }^{9}$ Maar hoe maken zij gebruik van hun manoeuvreerruimte?

\section{Onderzoeksvraag}

De aanhoudende kritiek vanuit onder meer de Raad van State roept de vraag op of wetgevingsjuristen tegenwoordig anders met de spanning tussen beleid en recht omgaan dan voorheen het geval was (voor zover we weten uit eerder onderzoek). Meer specifiek luidt onze onderzoeksvraag: op welke wijze gaan wetgevingsjuristen om met beleidsvoornemens die op juridische of rechtsstatelijke bezwaren stuiten en hoe rechtvaardigen zij in die gevallen hun rol? Binnen de beperkte handelingsruimte die wetgevingsjuristen hebben, kunnen zij zich meer of minder actief opstellen en meer of minder tegenspraak bieden. Het ene uiterste is dat zij geen enkele spanning ervaren en hun taak minimalistisch invullen ('u vraagt, wij draaien'); het andere uiterste is dat zij zich heel principieel opstellen en voortdurend nee verkopen aan hun collega's van de beleidsafdelingen. De kritiek vanuit de Raad van State doet vermoeden dat er te weinig ruimte is voor reflectie en tegenspraak vanuit de wetgevingsjuristen ten opzichte van hun beleidscollega's en dat zij hun taak minimalistisch invullen. Maar is dat ook zo? Hoe kijken wetgevingsjuristen daar zelf tegenaan? Deze en andere vragen hebben wij voorgelegd aan 24 wetgevingsjuristen op vijf ministeries.

\section{Leeswijzer}

Ons onderzoek bouwt voort op bevindingen van eerder empirisch onderzoek naar de wijze waarop wetgevingsjuristen in Nederland vorm en inhoud geven aan hun functie (par. 2). In par. 3 verantwoorden we onze onderzoeksaanpak. De bevindingen van ons onderzoek komen in paragraaf 4 aan bod. Achtereenvolgens bespreken we de reikwijdte van de functie van wetgevingsjurist (par. 4.1), het normenkader waarbinnen zij hun taken vervullen (par. 4.2), hun professionele rolopvatting (par. 4.3), hun antwoorden op de vraag wanneer zij wel of niet een grens trekken en tegenspraak bieden indien zij van mening zijn dat beleidsvoornemens indruisen tegen juridische of stuiten op rechtsstatelijke bezwaren (par. 4.4) en van welke strategieën zij gebruikmaken als die grens dreigt te worden 
overschreden (par. 4.5). In paragraaf 5 duiden wij de uitkomsten van ons onderzoek in het licht van de besproken literatuur en trekken wij - met de nodige voorzichtigheid gezien de beperkte omvang van het onderzoek - enkele conclusies.

\section{Eerder onderzoek naar de werkwijze van wetgevingsjuristen}

Veerman typeert het werkveld van wetgevingsjuristen als een 'arena' waarin veel belangen om voorrang strijden: een nationaal en internationaal spanningsveld van politiek, beleid en recht. ${ }^{10}$ Wetgevingsjuristen moeten zich niet alleen verstaan met hun bewindslieden en collega-beleidsambtenaren, maar ook met bewindslieden en ambtenaren van andere lidstaten, uitvoeringsorganisaties, maatschappelijke organisaties en andere belangengroepen. Deze betrokkenen hebben veelal uiteenlopende of soms tegenstrijdige belangen, die wetgevingsjuristen dan moeten zien te verenigen in wet- en regelgeving. Dit stelt hoge eisen aan hun professionaliteit. Veel komt aan op compromisvorming. ${ }^{11}$

In dat proces van compromisvorming delven juridische argumenten soms het onderspit; dat is op zichzelf geen nieuw verschijnsel. Al in de jaren zeventig en tachtig van de vorige eeuw nam de invloed van juristen binnen de overheid af, toen andere academici hun intrede deden in de departementen, in het bijzonder economen, bestuurskundigen en beleidskundigen. ${ }^{12}$ Volgens Snellen wordt sindsdien voortdurend strijd geleverd op vier vlakken: strijd om het beleid (de politieke rationaliteit), om de schaarse middelen (de financieel-economische rationaliteit), om de grondslag (de juridische rationaliteit) en om de technisch beste oplossing (de wetenschappelijke rationaliteit). Dat begint al bij de probleemdefinitie, als verschillende politieke en maatschappelijke belangen worden vertaald in politieke standpunten, en het zet zich voort gedurende het wetgevingsproces. Volgens Snellen is tussen de vier gezichtspunten geen algemeen geldige rationele ordening mogelijk. Vanuit elk van de vier rationaliteiten wordt gepoogd de eigen invloed te maximeren. Dat gaat dan ten koste van de andere rationaliteiten. ${ }^{13}$ Volgens Veerman is de facto in de (Nederlandse) praktijk uiteindelijk één rationaliteit doorslaggevend en dat is de politieke. ${ }^{14}$

Men kan zich afvragen of relativering van het recht en de afgenomen invloed van juristen (on)wenselijke verschijnselen zijn. Volgens Veerman kan het problematisch zijn dat de politieke rationaliteit het doorgaans wint van de juridische rationaliteit, maar is het niet per definitie een kwalijke zaak: de juridische rationaliteit heeft immers niet het monopolie op rechtvaardigheid of op het juiste evenwicht. ${ }^{15}$ Verhey laat zich kritischer uit over de afgenomen invloed van juristen. Naar zijn mening wordt soms 'bij de totstandkoming van wetgeving onder poli-

10 Veerman 2011.

11 Huls \& Stoter 2011; Veerman 2013.

12 Veerman 2011.

13 Snellen 1987, p. 6.

14 Veerman 2013, p. 30.

15 Idem. 
tieke druk te gemakkelijk heen gestapt over juridische en rechtsstatelijke beschouwingen'. ${ }^{16}$

\section{In een spagaat}

Mastenbroek en Peeters Weem hebben in 2009 onderzoek gedaan dat raakvlakken heeft met het onze. Zij hebben twintig wetgevingsjuristen en leidinggevenden geïnterviewd over hoe binnen departementen wordt omgegaan met Europeesrechtelijke verplichtingen. In hun conclusies onderscheiden zij drie rolopvattingen van wetgevingsjuristen: (1) uitvoerder van nationale beleidswensen, wiens loyaliteit primair ligt bij de minister en diens beleidswensen; (2) hoeder van het nationale recht, die het nationale recht bewaakt ook als dat niet strookt met Europese beleidswensen of Europees recht; (3) hoeder van het Europese recht, die op basis van doctrines van gemeenschapstrouw, voorrang en autonomie voorrang geeft aan het Europese recht boven het nationale recht. Een mogelijk vierde rolopvatting, die van uitvoerder van Europese beleidswensen, zagen zij in de praktijk niet voorkomen. ${ }^{17}$ Mastenbroek en Peeters Weem concluderen dat wetgevingsjuristen nogal eens in een 'spagaat tussen Brussel en Den Haag' zitten op momenten dat nationale beleidsvoornemens worden doorkruist door Europeesrechtelijke verplichtingen. ${ }^{18}$ Wetgevingsjuristen ervaren loyaliteitsconflicten tussen het nationale en het Europese werk. Zij proberen in eerste instantie de Europeesrechtelijke grenzen op een constructieve manier te handhaven tegen de beleidsdruk in. Dat lukt echter niet altijd. In dat geval wordt ofwel geen gehoor gegeven aan de betreffende beleidswensen ofwel wordt het Europese recht zodanig geïnterpreteerd, dat er geen conflict meer lijkt te zijn. Deze 'pragmatische visie op het Europese recht' lijkt volgens de auteurs in opmars te zijn en staat volgens hen op gespannen voet met de juridische professionaliteit van wetgevingsjuristen. ${ }^{19}$

\section{Rechtsrelativering}

Ook het eerder besproken proefschrift van Van Lochem over rechtsrelativering biedt aanknopingspunten voor ons onderzoek. Zijn onderzoek is gebaseerd op de jarenlange eigen ervaring van de auteur als overheidsjurist en (voormalig) directeur van de Academie voor Wetgeving en op publicaties van en interviews met directeuren Wetgeving en juridische zaken. Vanuit dit interne perspectief van de auteur abstraheert hij vier beroepsbeelden van overheidsjuristen ${ }^{20}$ op basis van hun standpunt ten aanzien van het verschijnsel rechtsrelativering (is dat in hun ogen wel of niet problematisch?) en hun professionele houding ten opzichte van politieke gezagsdragers (zien juristen hun eigen rol meer als partijdig of als neutraal?): ${ }^{21}$ 
1 De klassieke adviseur (geen relativering, neutrale rol) richt zich nauwgezet op zijn verantwoordelijkheid als jurist. Hij beschouwt het als zijn eer en taak om tegenspraak te leveren, maar doet dat vanuit een neutrale rol. Hij is een kritisch adviseur en een loyale uitvoerder: de minister is uiteindelijk verantwoordelijk.

2 De creatieve adviseur (geen relativering, partijdige rol) stelt zich meer partijdig op. Hij ziet het als zijn taak om de rechtsstatelijkheid van het overheidsbeleid te bevorderen en is van mening dat die taak niet louter aan politieke gezagsdragers kan worden overgelaten. Hij heeft kortom een missie.

3 De politieke adviseur (wel relativering, partijdige rol) is sterk geneigd tot meedenken en meebesturen. Hij heeft minder ontzag voor de regeltjes en vindt rechtsstatelijkheid een groot woord. Het recht wordt beschouwd als dienstbaar aan beleid. Hij stelt zich op als advocaat van de ambtsdrager en signaleert en vermijdt risico's in relatie tot de beleidsdoelen van de ambtsdrager.

4 De flexibele adviseur (wel relativering, neutrale rol) is van mening dat je met het recht alle kanten uit kunt. Hij vindt altijd wel een passende juridische redenering. ${ }^{22}$

Van Lochem signaleert in de loop der tijd een verschuiving van de eerste variant (adviseren) naar de derde (meedenken en meebesturen). Dat beeld komt overeen met dat van juristen werkzaam in de gemeentelijke praktijk, waar men ook een meer partijdige adviseur voor ogen lijkt te hebben. ${ }^{23}$

\section{Relevantie voor ons onderzoek}

De beschreven onderzoeken geven een goed beeld van de variatie aan rolopvattingen van wetgevingsjuristen. Een onderbelicht punt in de literatuur dat wij verder zullen uitdiepen, is in welke gevallen wetgevingsjuristen zichzelf geroepen voelen tegenspraak te leveren en hoe zij dat rechtvaardigen. Verder is het de vraag of wij eenzelfde variëteit aan rolopvattingen tegenkomen of dat de door de eerdere onderzoekers geconstateerde ontwikkelingen naar een meer pragmatische opstelling (Mastenbroek \& Peeters Weem) dan wel naar die van politieke adviseur (Van Lochem) zich heeft voortgezet en de beroepsgroep in dat opzicht homogener is geworden. In de conclusie gaan we hier nader op in.

\section{Aanpak en methode van onderzoek}

Dit onderzoek betreft een kleinschalig, kwalitatief onderzoek. Tussen juni en september 2018 zijn 24 interviews afgenomen met wetgevingsjuristen op vijf verschillende ministeries: Justitie en Veiligheid; Binnenlandse Zaken; Volksgezondheid, Welzijn en Sport; Economische Zaken en Klimaat; Financiën. Voor deze ministeries is gekozen, omdat de meeste wetgeving binnen deze ministeries tot stand komt en wetgevingsjuristen daar herkenbaar aanwezig zijn. Met uitzonde- 
ring van het ministerie van Financiën zijn de wetgevingsjuristen die wij hebben gesproken werkzaam in een aparte directie. Bij het ministerie van Financiën is de functie van wetgevingsjurist en beleidsmedewerker geïntegreerd en hebben wij gesproken met juristen die een substantieel deel van hun tijd besteden aan het ontwikkelen van wetgeving.

Voor de selectie van respondenten hebben wij de directeuren van de afdeling waarbinnen de juristen werkzaam zijn, verzocht om namen van wetgevingsjuristen, zowel mannen als vrouwen, variërend in werkervaring (zowel beginnende wetgevingsjuristen, als ervaren tot zeer ervaren krachten). Op deze wijze kon een divers gezelschap worden bevraagd. Wij merken daarbij wel op dat in onze respondentengroep senior medewerkers oververtegenwoordigd zijn, hetgeen onze resultaten enigszins vertekend kan hebben. Aangezien wij vooral geïnteresseerd zijn in dilemma's van wetgevingsjuristen die complexe dossiers moeten behandelen, kwam het ons echter ook goed uit: complexe dossiers worden immers doorgaans door de meest ervaren krachten behandeld (de interviews bevestigen dit beeld). Ervaren medewerkers hebben bovendien een voorbeeldfunctie voor de minder ervaren medewerkers. Gezien de beperkte omvang van het onderzoek en de mogelijke selectiviteit ten aanzien van onze respondenten, kunnen wij geen generaliserende uitspraken doen die verder strekken dan onze respondentengroep.

Wij hebben de eerste vijftien interviews samen afgenomen, de resterende respondenten hebben wij om praktische redenen onderling verdeeld. De vraaggesprekken vonden plaats op de werkplek van de respondenten. In de interviews hebben we respondenten, na een aantal inleidende en algemene vragen, gevraagd te reageren op uiteenlopende standaardbeelden over wetgevingsjuristen (de jurist als 'nee-zegger', als 'scribent van beleid' en als 'spitsroedenloper'). Dit leek ons een geschikte methode om het vraaggesprek te stimuleren en onze respondenten te verleiden stelling te nemen. $\mathrm{Zij}$ reageerden daar vrij neutraal op, over het algemeen herkenden zij die beelden wel. Niettemin bleek duidelijk dat de meesten niet als 'nee-zegger' te boek willen staan (zie par. 4.3). Dat bood aanknopingspunten om door te vragen wanneer respondenten het toch noodzakelijk vinden om grenzen te stellen en nee te zeggen tegen verzoeken. ${ }^{24}$ In de interviews zijn nog andere onderwerpen bevraagd, bijvoorbeeld hoe wetgevingsjuristen meer in het algemeen aankijken tegen het wetgevingstraject en de adviezen die zij gedurende dat traject moeten inwinnen, welke trajecten zij als succesvol dan wel als mislukt hebben ervaren, en op welke wijze zij contacten met belanghebbenden en belangengroeperingen onderhouden. Over deze onderwerpen zal mogelijk nog elders worden gepubliceerd.

De interviews zijn geanonimiseerd en integraal uitgetypt. ${ }^{25}$ Vervolgens zijn ze gecodeerd en geanalyseerd met behulp van het coderingsprogramma Atlas.ti. De interviewfragmenten zijn enigszins geredigeerd om ze beter leesbaar te maken. Passages die tot individuele ambtenaren herleidbaar zouden zijn, zijn achterwege gelaten. 


\section{Achtergrond van onze respondenten}

Onze respondentengroep bestaat uit elf mannen en dertien vrouwen. Vier daarvan kunnen als junior worden getypeerd: zij hebben minder dan vijf jaar werkervaring. Zes respondenten hebben tussen vijf en tien jaar werkervaring en veertien respondenten kunnen als senior worden getypeerd: zij hebben meer dan tien jaar werkervaring. Vermeldenswaardig is nog dat vier respondenten gepromoveerd zijn en één nog aan een proefschrift werkt. Twee hebben een nevenfunctie in de rechterlijke macht als rechter- respectievelijk raadsheer-plaatsvervanger. Verschillende respondenten hebben publicaties in vaktijdschriften op hun naam staan en zijn als docent verbonden aan opleidingen, waaronder de Academie voor Wetgevingsjuristen. Negen respondenten hebben zelf deze Academie afgerond of zijn daar nog mee bezig. Twee respondenten zijn als 'zij-instromer' het vak ingerold, vanuit de advocatuur en een universiteit. De overige respondenten waren al voor de oprichting van de Academie voor Wetgevingsjuristen in september 2001 werkzaam bij de overheid.

\section{Bevindingen van het onderzoek}

In deze paragraaf presenteren wij onze bevindingen. Om te beginnen schetsen wij een beeld van de werkzaamheden van wetgevingsjuristen en de professionele standaarden waaraan hun werk dient te voldoen. Vervolgens gaan wij dieper in op de manier waarop zij hun werk doen, aan de hand van gangbare typeringen van wetgevingsjuristen. Tot slot staan wij stil bij de wijze waarop zij omgaan met spanningen en dilemma's.

\subsection{Meer praten dan schrijven}

\section{- Een veelzijdige functie}

Wetgevingsjuristen doen veel meer dan louter wetteksten schrijven. Zij staan voortdurend in contact met collega's van beleidsafdelingen, juristen van andere departementen en veelal ook met 'het veld'. Verder nemen wetgevingsjuristen deel aan overleggen met uitvoerings- en toezichthoudende instanties. De primaire verantwoordelijkheid voor het overleg met externe organisaties ligt op de meeste departementen weliswaar bij de beleidsafdelingen, maar wetgevingsjuristen schuiven geregeld aan. Het overleg met externe organisaties wordt vooral gebruikt om inhoudelijke input te krijgen op wetsvoorstellen, de implementatie voor te bereiden of om draagvlak te creëren. Omgekeerd proberen die externe organisaties ook te lobbyen om hun wensenpakket doorgevoerd te krijgen. ${ }^{26}$ 'Het klassieke beeld van een wetgever die heel diep zit na te denken in zijn kamertje, klopt dus niet', aldus een van onze respondenten. Het uiteindelijke schrijfwerk aan de feitelijke wettekst is slechts een klein onderdeel van hun taak. Bovendien schrijven op veel ministeries de beleidsambtenaren de algemene toelichting op de 
wetteksten (zoals de memorie van toelichting). Het zwaartepunt ligt dus op samenwerking en onderhandeling met uiteenlopende partijen, vooral over de aard en omvang van het te regelen probleem en op mogelijke varianten van oplossingen.

Afhankelijk van de taakverdeling tussen de beleidsafdelingen en de afdeling Wetgeving en Juridische Zaken (dat verschilt per ministerie) en van hun positie binnen de eigen afdeling hebben wetgevingsjuristen meer of minder vergaande taken. Beginnende juristen starten doorgaans met eenvoudige klussen waarmee ze het wetgevingstraject van begin tot eind onder de knie krijgen, zoals eenvoudige, technische wetswijzigingen en implementatie van Europese regelgeving. De meest ruime taakomschrijving hebben zogenoemde coördinerend raadsadviseurs op het ministerie van Justitie en Veiligheid. Zij zitten in de positie om naast alle verzoeken die vanuit de politiek komen, soms ook zelf nieuwe voorstellen voor wetgeving te doen. Zij nemen ook wel zelfstandig het initiatief om in de voorbereidingsfase bepaalde deskundigen of maatschappelijke organisaties te consulteren. Het komt voor dat zij de gehele memorie van toelichting schrijven (niet alleen de artikelsgewijze toelichting, maar ook het algemene deel) en zij hebben direct toegang tot de bewindspersoon.

\section{- Beroepstrots}

Uit onze vraaggesprekken komt naar voren dat veel wetgevingsjuristen professionele bevrediging en trots putten uit het feit dat ze voor een complex maatschappelijk vraagstuk een passende juridische oplossing hebben weten te vinden, die ook nog eens het Staatsblad heeft gehaald. Dit blijkt bijvoorbeeld uit de volgende citaten van verschillende wetgevingsjuristen.

'De leukste wetsvoorstellen zijn de wetsvoorstellen waarbij ze bij je komen en zeggen: "we hebben een probleem, verzin een oplossing". En dat het dat uiteindelijk dan ook wordt. Dat is heel leuk. (...) Je zit achter je bureau en ziet een probleem en denkt: hoe gaan we dit nu oplossen? Dan verzin je een oplossing, dus het creatieve proces. Maar soms is het zo, sommigen zijn voor, anderen zijn tegen en dat je het dan toch, tegen de stroom in, uiteindelijk in het Staatsblad krijgt, dat is natuurlijk het leukst.'

'We gaan altijd uit eten met de afdeling als een wetsvoorstel van een collega het Staatsblad heeft gehaald.'

'Daarom zeggen mensen ook: het is een ambacht. En dat geloof ik ook echt, zonder mezelf belangrijk te willen maken. Ergens heeft het iets van een architect ook, dat je echt een bouwwerkje maakt dat moet kloppen en moet doen waarvoor het is bedoeld. En zelf kan ik daar de schoonheid wel van inzien, als een wet mooi bondig is.'

\section{- Competenties}

Uit de combinatie van het juridisch-inhoudelijke en de aspecten van samenwerking en onderhandeling blijkt wel dat het werk van de wetgevingsjurist brede 
kennis en vaardigheden vergt. Niet alleen is gedegen juridische kennis van het nationale en het Europese en internationale recht vereist, maar ook inzicht in maatschappelijke vraagstukken en politiek-bestuurlijke verhoudingen. Daarnaast is van groot belang het communicatieve vermogen om bij collega's van de beleidsafdeling de juiste snaar te raken en zich te verstaan met bewindslieden en parlementariërs. Een leidinggevende van wetgevingsjuristen vat een en ander kort en krachtig samen: 'Een goede wetgevingsjurist heeft een vergrootglas en een helikopter.'

\subsection{Het normatieve handelingskader van de wetgevingsjurist}

In de voorbereiding van ons onderzoek viel het ons op dat er weinig concrete normen voorhanden zijn die richtinggevend kunnen zijn voor het handelen van wetgevingsjuristen. Anders dan bij de klassieke juridische togaberoepen, zoals advocaat of rechter, het geval is, is er geen duidelijke beroepsethiek voor wetgevingsjuristen. De bestaande regels bieden wel enige aanknopingspunten voor een kritische opstelling van wetgevingsjuristen, maar blijven noodgedwongen vaag. Zo staat in de eed of belofte een passage waarin ambtenaren onder meer 'eerbiediging van de Grondwet en van alle overige wetten van ons land zweren of beloven'. In de gedragscode voor rijksambtenaren valt onder meer te lezen:

'Trouw aan de publieke zaak staat (...) voorop en stijgt uit boven loyaliteit: je hoort je bewust te zijn van je verantwoordelijkheden en, ook als het moeilijk is, het juiste te doen. Zelfs als dit je in een loyaliteitsconflict brengt binnen de organisatie. Dit doet een groot beroep op jouw oordeelsvermogen, omdat iedere situatie weer anders is. Daarbij dien je het algemeen belang en houd je rekening met de gerechtvaardigde belangen van degenen die een beroep op jou doen. Dit vereist betrokkenheid, wijsheid en moed.'27

Desgevraagd vinden vrijwel alle ondervraagde wetgevingsjuristen het ontbreken van een specifieke, op wetgevingsjuristen toegesneden beroepsethiek geen probleem. Over het algemeen zijn de respondenten die wij hebben gesproken meer gericht op het technocratische normenkader waarmee het wetgevingsproces is omgeven: bijvoorbeeld de eisen waaraan wetgeving moet voldoen volgens de Aanwijzingen voor de regelgeving ${ }^{28}$ of de eisen die de verschillende advies- en toetsingsorganen stellen, waaraan wetgevingsvoorstellen moeten of kunnen worden voorgelegd alvorens deze bij de Tweede Kamer kunnen worden ingediend. Zij worden bovendien geacht te werken volgens het Integraal Afwegingskader (IAK), waarin aan de hand van zeven vragen nader gemotiveerd moet worden wat nut en noodzaak zijn van nieuwe regelgeving, of er betere alternatieven voorhanden zijn, wat de gevolgen zijn voor direct betrokkenen en of de regeling uitvoerbaar en handhaafbaar is.

27 Gedragscode Integriteit Rijk 2017/2018, p. 8.

28 Deze aanwijzingen worden voor wetgevingsjuristen ontsloten en van een toelichting voorzien op de Kennisbank Wetgeving en Juridische Zaken, zie www.kcwj.nl/kennisbank/aanwijzingen-voorde-regelgeving-0. 
Hoewel onze respondentengroep te klein is om een representatief beeld te kunnen schetsen van de wijze waarop wetgevingsjuristen met het IAK omgaan, ${ }^{29}$ valt wel op dat volkomen verschillend wordt gedacht over het belang van het IAK. Waar de een het IAK 'heel belangrijk' vindt, benadrukt een ander dat die vragen zo basaal zijn dat ze al volledig geïncorporeerd zijn in het denken van wetgevingsjuristen, en beschouwt weer een ander het IAK meer als een afvinklijstje dat ook nog even ingevuld moet worden. Bij het ene ministerie (bijv. Justitie en Veiligheid) zien wetgevingsjuristen het afwegen van de vragen van het IAK als belangrijk onderdeel van hun taak, terwijl dit bij het andere ministerie (bijv. Volksgezondheid) als primaire taak wordt gezien van de collega's van de beleidsafdelingen. Er zijn ook respondenten die aangeven dat als een voornemen is neergelegd in het regeerakkoord, het IAK nog louter plichtmatig wordt doorlopen. De beslissing om met nieuwe wetgeving te komen, is dan immers al gemaakt.

\subsection{De wetgevingsjurist als nee-zegger of mee-beweger?}

Hoe kijken respondenten aan tegen standaardbeelden die over hen worden geschetst in de literatuur? ${ }^{30}$ Twee uitersten die in dit verband naar voren komen. zijn de wetgevingsjurist als 'nee-zegger' en als 'mee-beweger'. Het eerste type is kritisch over voorgenomen wetgeving en stelt zich afhoudend op. Hij ziet vooral belemmeringen en uit bezwaren, gelet op de verhouding tot hogere regelgeving en/of het systeem van de wet. Uit eerder onderzoek is gebleken dat dit type wetgevingsjurist door zijn collega's van de beleidsafdelingen wordt ervaren als hindermacht, als 'remmer in vaste dienst'. ${ }^{31}$ Het tweede type is flexibel en stelt zich pragmatisch op. Vindingrijk als hij is, weet hij er altijd wel een mouw aan te passen. Wij hebben onze respondenten deze typeringen, beter gezegd stereotyperingen, voorgelegd en hun gevraagd om een reactie.

\section{- De nee-zegger}

Onze respondenten herkenden het eerste beeld van de nee-zegger of dwarsligger wel, zij het aarzelend. In het verlengde daarvan erkenden zij dat het soms nodig is om duidelijk nee te zeggen, om krachtig aan de noodrem te trekken, bijvoorbeeld omdat een voorstel of een plan botst met grondrechten, indruist tegen een bestendige lijn in de jurisprudentie of niet in het wettelijk systeem valt in te passen. Echter, zij doen dit spaarzaam. Veeleer proberen zij deze positie zo veel mogelijk te vermijden, omdat zij die onwenselijk achten. Het is immers niet effectief: nee zeggen leidt vaak tot een impasse of dat zij zichzelf buiten spel plaatsen. Wetgevingsjuristen van tegenwoordig proberen juist het (negatieve) imago van dwarsligger van zich af te schudden en constructief mee te denken. Illustratief is het volgende citaat.

'Het beeld leeft zeker. Vooral bij beleidsmedewerkers. Op het moment dat je een jurist erbij roept, dan wordt het ingewikkeld, dan mag je dingen niet 
meer. Dat is echt een constant beeld waar je mee in gevecht bent. Dat je wil laten zien van: ik denk méé, ik probeer actief alternatieven aan te dragen als iets niet kan.'

Vervolgens riposteerden zij dat nee zeggen of dwarsliggen niet moet worden verward met een kritische houding. Want dat is wat wetgevingsjuristen nu eenmaal doen: kritische vragen stellen omwille van de kwaliteit van wetgeving. Is het echt nodig de wet te wijzigen? Is het nuttig? Zijn er geen alternatieven denkbaar, kan het niet anders? Zij zien het als hun taak om niet te snel mee te gaan in de vluchtige en veranderlijke wens van politici en beleidsmakers om de wet aan te passen. Vooral als het probleem nog onvoldoende doordacht is en de beoogde oplossing weer nieuwe problemen oproept, aldus een respondent.

'Sommige mensen beginnen meteen te roepen om oplossingen en dan denk ik: ja, wacht eens even, zit dat nou wel zo? Als je dat nee-zegger of dwarsligger wil noemen ... Het kan niet zo zijn dat je voor het eerste beste probleem de wet gaat wijzigen. Je moet wel even ... [goed bedenken]: Als je gaat wijzigen, dan kan het zijn dat het bouwwerk dat goed in elkaar zit niet meer klopt ... Dat is een zekere gereserveerdheid tegenover de waan van de dag.'

Een respondent merkt op:

'Soms zeg ik wel eens eigenlijk is mijn belangrijkste taak om wetten tegen te houden, omdat er al genoeg zijn ...'

Ook een andere respondent wijst erop dat 'nee zeggen' soms noodzakelijk is:

'Een belangrijke taak van de wetgevingsjurist is om te zorgen dat de wet níet hoeft te worden gewijzigd en om na te gaan of wat men wil bereiken, niet binnen het bestaande kader al kan. Want het is heel gemakkelijk om te roepen: we gaan de wet wijzigen! Daarna is het wel klaar voor degene die dat heeft gezegd, de Minister, maar voor ons begint dan het zwoegen, zeg maar. Dan ben je vijf jaar verder en dan weet niemand meer waarom het moest ... Dus, je moet zo veel mogelijk nagaan of nieuwe wetgeving echt wel noodzakelijk is. Dus in die zin ben je een nee-zegger.'

Kortom, nee zeggen is soms nodig, maar bij voorkeur proberen wetgevingsjuristen dit te vermijden, want het is doorgaans weinig productief. Liever reiken zij alternatieven aan en denken constructief-kritisch mee, het liefst in een vroeg stadium van beleidsontwikkeling.

\section{- De mee-beweger}

Het beeld van de mee-beweger of u-vraagt-wij-draaien daarentegen, kwam volgens onze respondenten dichter bij de waarheid. Zeker als het gaat om politiek gevoelige onderwerpen, kwesties die zwaar wegen voor de minister of het kabinet. Omdat het in het regeerakkoord staat of de bewindslieden daarover een toezeg- 
ging hebben gedaan aan het parlement. Of omdat het gaat om de onontkoombare implementatie van Europese regelgeving. In die gevallen rest hun niet veel anders dan als loyale ambtenaar het beste te maken van het betreffende wetsvoorstel. Een respondent verwoordt het als volgt:

'Als het echt een politieke keuze is, dan heb ik mij daarbij neer te leggen. Ik ben niet de minister... En het gebeurt regelmatig dat ik vind dat ik wetten moet maken die onverstandig zijn, niet zo vaak, maar het komt weleens voor. $\mathrm{Ja}$, dat zij dan zo. Ik vind het mijn taak om de departementsleiding daarop te wijzen. Als zij vervolgens zeggen: dat kan wel zo zijn maar wij gaan er toch mee door, dan is mijn kritische rol uitgespeeld.'

Tegelijkertijd zien wetgevingsjuristen zich niet graag gereduceerd tot louter vormgever-van-beleid. Dat zou afbreuk doen aan hun rol en verantwoordelijkheid als expert. Dus benadrukken zij in de interviews wederom het belang van het constructief-kritisch meedenken, op basis van hun verantwoordelijkheid voor de kwaliteit van wetgeving. Zij zijn degenen die risico's signaleren en bewaken, degenen die de consistentie van het wettelijk systeem in het oog houden evenals de uitvoerbaarheid en handhaafbaarheid van de wet.

Deze rol achten zij bovendien veel effectiever dan de rol van nee-zegger. In deze benadering hebben zij immers meer ruimte om te manoeuvreren, dan in de eerste variant waarin ze met hun rug tegen de muur dreigen te komen staan. Door een constructief-kritische opstelling kunnen zij veel meer invloed uitoefenen, bijvoorbeeld door de probleemdefinitie (opnieuw) ter discussie te stellen en nieuwe opties ter tafel te brengen. Zo verbreden zij hun speelveld. Tegelijkertijd zijn ze in deze rol inhoudelijk afstandelijker, als een neutrale adviseur. Daardoor hebben ze minder te verliezen.

Concluderend kan worden gesteld dat de wetgevingsjuristen die wij hebben gesproken zich het best herkennen in de rol van constructief-kritisch meedenker. Ze zijn kritisch over nut en noodzaak van wijziging van wet- en regelgeving en beschouwen het bieden van tegenwicht wel degelijk als onderdeel van hun werk. Wel zijn zij zich ervan bewust dat ze daarbij behoedzaam en selectief te werk moeten gaan ('pick your battles', zoals een respondent het zegt). Zij kunnen niet op elke slak zout leggen, dat zou contraproductief werken. De kunst is om zich effectief in te zetten in discussies die er voor de jurist écht toe doen. Welke zijn dat?

\subsection{Rode vlaggen en grijze gebieden}

'Er wordt wel gezegd: bij herinvoering van de doodstraf, dan neem ik ontslag. Iedere jurist zal zeggen: er is een buitengrens, maar niemand weet waar die precies ligt.'

In welke gevallen trekken onze respondenten een grens in wat zij wel of niet juridisch of rechtsstatelijk te rechtvaardigen vinden? Uit de vraaggesprekken komt naar voren dat onze respondenten in elk geval een krachtig tegengeluid zouden laten horen als een plan of een voorstel in strijd zou zijn met hogere regelgeving, 
waaronder de Grondwet en Europese regelgeving. Verder noemen zij strijdigheid met de jurisprudentie van de hoogste rechtscolleges. In dit verband wordt ook vaak genoemd het ontbreken van een wettelijke grondslag (het legaliteitsbeginsel), bijvoorbeeld voor het opstellen van een algemene maatregel van bestuur. Ook wel een belangrijk punt, maar niet van doorslaggevend belang, vinden onze respondenten dat een plan of een voorstel niet goed valt in te passen binnen de wettelijke systematiek, niet goed uitvoerbaar of handhaafbaar is of weinig toevoegt en eigenlijk vooral symbolische waarde heeft. Een respondent licht als volgt toe waar hij de grens trekt:

'Kijk, sommige dingen daar moet je ook gewoon pal voor staan als jurist, ook als wetgevingsjurist. Als het in strijd komt met bepaalde grondrechten, of als het rechtsstatelijk gewoon niet kan, dan moet je het gewoon durven benoemen. Ook op het moment dat je bij een minister zit, en die stelt iets voor waarvan je denkt: sorry, maar dit kan natuurlijk gewoon echt niet. Dan moet je het ook gewoon kunnen roepen. En dat is ook een kracht die je als wetgevingsjurist moet hebben inderdaad: je moet ook wel pal staan voor de rechtsstaat en sommige belangen die niet alleen maar juridisch zijn, maar wel in juridische regels vervat zijn - want dat wordt heel vaak door elkaar gehaald. Beleidsmensen hebben het vaak over die staatssteunregels en zo, en dat is allemaal heel vervelend dat je niet zomaar gewoon geld kunt uitdelen (...) Daar zitten ook economische belangen achter van eerlijke concurrentie (...). Dat is wederzijds, wij willen ook niet dat een bedrijf dat in Frankrijk zijn diensten aanbiedt daar problemen krijgt, omdat de Franse bedrijven allemaal geld toegestopt krijgen. Dan moet je altijd wel proberen ook uit te leggen. En niet alleen maar zeggen het kan niet. Nee, het kan niet om een reden. Een goed jurist weet dat dus ook over te brengen.'

\section{- Relativering en pragmatisme}

Niet iedere wetgevingsjurist ziet zich echter als hoeder van de rechtsstaat. Sommigen zijn terughoudender of stellen zich meer pragmatisch op. Zo vertelt een respondent:

'Nee ... ik vind discussies daarover heel boeiend en interessant, maar wat is een democratische rechtsstaat? Ja, ik vind het lastig om dat soort bewoordingen ..., om mezelf zo te noemen ik vind dat veel te veel, veel te pff ...'

Volgens deze respondent waren er meerdere collega's die het wetsvoorstel inzake het 'boerkaverbod' niet voor hun rekening wilden nemen, maar:

'(U)iteindelijk moet iemand het doen. (...) Ik sta daar pragmatischer in. Ik vind het zelf lastig, maar hoe ouder ik word, hoe pragmatischer ik ben. Dus ik denk dat ik het wel gedaan zou kunnen hebben.' 
Veel hangt af van de manier waarop de wetgevingsjurist zijn bezwaren formuleert en presenteert. Het is de toon die de muziek maakt. Zo blijkt het relaas van deze wetgevingsjurist.

'Als het naar ons oordeel in strijd met het EVRM of Europese regelgeving is, dan moeten we nee verkopen. Dan zeggen we niet jongens, stop er allemaal maar mee, maar dan is het meer van "deze regeling is in strijd met bijvoorbeeld het recht op eigendom, dit kunnen we niet doen”. Of, bijvoorbeeld met bezuinigingsopgaven zie je dat heel vaak, dat dingen per direct stopgezet moeten worden. Dan is er bepaalde jurisprudentie die maakt dat er een overgangsregime moet zijn of wat dan ook. Dan moet daar vanuit de financiële kant over nagedacht worden, dat er alternatieven bedacht moeten worden voor dat direct stopzetten. (...) In beginsel overtuig je mensen er wel mee, zeker als het gevolgen kan hebben. Je schetst natuurlijk ook de risico's. Natuurlijk is er soms best wel een grijs gebied, dan is het risico dat de wetgeving onverbindend wordt verklaard of dat er onrechtmatige wetgeving tot stand is gebracht die tot schadevergoeding gaat leiden. In sommige gevallen kan het een bewuste afweging zijn om dat risico te nemen, maar dat is dan wel een politieke afweging die gemaakt moet worden. En dat heb ik wel meegemaakt, dat je dat voorlegt aan de minister en dan is het aan de minister om een keuze te maken.'

De citaten maken ook duidelijk dat het niet alleen om nee zeggen gaat, maar ook om meedenken en risico's inschatten en afwegen. Opvallend is dat de hierboven geciteerde respondent voor de beslissing over die risico's meteen naar de bewindspersoon verwijst en zich aldus zelf hiervan distantieert. Hiermee komen we op de vraag wat wetgevingsjuristen doen als in hun ogen de hiervoor aangegeven grenzen dreigen te worden overschreden. Bewegen zij dan mee of bieden zij tegenwicht?

\subsection{Uitwegen en oplossingen}

\section{- De weigerambtenaar}

Is het om te beginnen denkbaar dat wetgevingsjuristen een dossier zouden kunnen weigeren? Bestaat er zoiets als de weigerambtenaar onder de wetgevingsjuristen? Vrijwel alle respondenten zijn van mening dat een wetgevingsambtenaar zijn persoonlijke overwegingen opzij moet kunnen zetten. Maar stel dat een ambtenaar gewetensbezwaren heeft om dossiers op een bepaald onderwerp te behandelen, dan kan hij bij zijn leidinggevende wel aangeven dat hij liever een ander dossier toebedeeld krijgt. Volgens onze respondenten gebeurt dat echter zelden of nooit; zelf hebben zij daar in elk geval geen ervaring mee. Voor zover ze het al denkbaar achten, zou het niet gaan om juridisch-inhoudelijke redenen (beroepsmoraal), maar bijvoorbeeld om religieuze redenen, bijvoorbeeld bij medischeethische dossiers (persoonlijke moraal). Een leidinggevende zegt hierover: 
'Als iemand naar mij toe zou komen en dat een keer zou hebben, zou ik zeggen: prima, we zoeken een ander onderwerp voor je. Er zijn genoeg onderwerpen. Maar als jij voortdurend persoonlijk in gewetensnood komt, dan vind ik dat je iets anders moet gaan doen.'

Incidenteel weigeren is dus niet ondenkbaar. Sommige dossiers, zoals het boerkaverbod, verplichte anticonceptie of sterilisatie van verstandelijk gehandicapten of een aantal dossiers op het gebied van het vreemdelingenrecht liggen volgens respondenten wel gevoelig. Van sommige van dergelijke dossiers kunnen zij zich voorstellen dat zijzelf of collega's die zouden teruggeven.

\section{- De escalatieladder}

Omdat weigeren geen optie is, behoudens eerdergenoemde niet vaak voorkomende uitzonderingen, hanteren wetgevingsjuristen andere strategieën als zij worden geconfronteerd met omstreden beleidsvoornemens. Eén ervan is escalatie, niet ongebruikelijk binnen de ambtelijke verhoudingen. Dat wil zeggen dat zij op opeenvolgende ambtelijke niveaus, tot en met het overleg met de bewindslieden, schriftelijk of mondeling een duidelijk negatief advies uitbrengen. Een respondent licht dit als volgt toe.

'Ik bedoel: op het moment dat er een nota naar de minister gaat met een bepaald voorstel over welke kant we op moeten gaan, en daar zit een juridisch punt in, er moet wetgeving voor gemaakt gaan worden, of er zit een juridisch argument in, dan moeten wij ook een mede-paraaf verlenen. En dat gebeurt nog weleens, dat wij zeggen: "ja sorry, maar hier gaan wij geen mede-paraaf op verlenen”. En dan heb je inderdaad gewoon een hard punt inderdaad van ja, dit gaat niet langs ons. En dan kun je wel gewoon met je vuist op tafel slaan.'

De knoop moet dan maar op een hoger niveau worden doorgehakt. In een van de voorgaande citaten werd daar ook al gewag van gemaakt. Maar het negatieve advies gaat doorgaans wel vergezeld van alternatieven.

'Als de minister beslist, we gaan het zo doen, dan is het uiteindelijk gewoon mijn taak om dat uit te voeren. Alleen vind ik, je moet hem van tevoren wijzen op de risico's en nagaan of hij het dan nog steeds zo wil. Ik vind ook dat je suggesties moet aandragen om het beter of anders te maken. Dat jij zegt, hier zit een probleem, wilt $\mathrm{u}$ het echt, oké, maar dan kunt $\mathrm{u}$ misschien beter deze maatregelen nemen om te zorgen dat u dat probleem deels ondervangt.'

\section{- Polderen}

Tegelijkertijd geven onze respondenten aan escalatie niet de voorkeur. Het kan nodig zijn, maar het zet de onderlinge ambtelijke verhoudingen onder druk. Meer in het algemeen geeft het hun het gevoel een achterhoedegevecht te voeren en in een isolement te raken. Zoals eerder aan de orde kwam, proberen zij dan ook te voorkomen de rol van dwarsligger te moeten spelen en uit de fuik te blijven van 
het nee-zeggen. Dat doen zij door in een vroeg stadium van beleidsontwikkeling mee te denken. Bijvoorbeeld door het probleem te herdefiniëren, nieuwe opties te creëren en alternatieven aan te dragen. Door uitzonderingen te creëren, hardheidsclausules op te nemen of compensatieregelingen voor te stellen. Met andere woorden, zij schuiven op naar het beleid en nemen de rol aan van beleidsmaker. Een wetgevingsjurist licht het belang hiervan als volgt toe:

'Want kijk, als je op de rem moet gaan staan dan is dat vaak een teken dat je in de voorfase te weinig poten aan de grond hebt gekregen. Want als je bij de minister nog moet gaan komen met de mededeling wat $\mathrm{u}$ nu voorstelt, dat kan echt niet, dat betekent dat je in de voorfase, voordat er iets bij de minister komt, al niet je punt hebt kunnen halen. Juist in de voorfase kun je als wetgevingsjurist heel veel betekenen, in mijn ogen.'

Sterker nog, een deel van de respondenten zag eigenlijk helemaal geen tegenstelling of probleem. De gepercipieerde strijdigheid met hogere regelgeving is in hun ogen een kwestie van interpretatie en van risico-inschatting. Volgens deze groep is voor elk juridisch probleem uiteindelijk wel een oplossing te vinden. Het is geen kwestie van zwart-wit, maar er is altijd een grijs gebied. En dat is nu juist waar wetgevingsjuristen op hun best zijn. Onderstaande uitspraken van verschillende respondenten maken dit inzichtelijk.

'Er is altijd wel een betoog te houden dat het [het wetsvoorstel] stand kan houden als je het op een bepaalde manier inricht. Maar ja, er zijn ook andere benaderingswijzen denkbaar. Er is op voorhand niet precies te bepalen wat de uitkomst zal zijn als het aan de rechter wordt voorgelegd. Dan zit je dus meer in de sfeer van de risicobeheersing en risicoverkleining.'

'Een van mijn stokpaardjes is: denk erom jongens, juridisch kan bijna alles. We hebben nou net weer een nota over een bepaald onderwerp, waarvan ook juristen zeiden: dat is eigenlijk niet wenselijk om het zo te regelen. Waarvan ik heb gezegd, dat kan wezen, maar juridisch kan het wel. Dan gaan we toch in de nota zetten: juridisch kan het. Dus voordat je zegt van: dat kan niet ... Grondrechten is een mooi voorbeeld, wij hebben hier veel met grondrechten te maken en ja die hebben toch wel een beetje het aureool van zodra de grondrechten in beeld komen, dan kan er niks. Dat is helemaal niet waar. Ik heb zelf hier ooit nog een wetsvoorstel gemaakt waarin heel erg grondrechten in het geding waren, ja, maar ja, er zit altijd een tweede lid bij waarin staat hoe je dan zo'n grondrecht in kunt perken ...'

- Loyaliteit

Al met al lijken onze respondenten eerder mee te bewegen met beleidswensen, ook als daar juridisch problematische aspecten aan zitten, dan tegenwicht te bieden. Hun loyaliteit ligt primair bij de bewindslieden.

'Uiteindelijk ben je ambtenaar en doe je wat de minister wil dat je doet.' 
Zij verantwoorden deze rolopvatting door te verwijzen naar de democratische legitimatie van de bewindspersoon. Zij lichten dat als volgt toe:

'Ik denk dat je je ook moet afvragen, ik denk dat heel veel wetgevingsjuristen dat ook gedaan hebben, van: naar wie ben ik nou loyaal, waarom zit ik nou hier? Voor mij is dat, misschien een beetje een dooddoener, de democratische rechtsstaat. Dus niet alleen de rechtsstaat, maar de democratische rechtsstaat, dus met inbegrip van het systeem, het politieke systeem. Dus het feit dat een Kamerlid iets wil en ik denk van dat is een heel slecht idee, ik vind dat je dan als ambtenaar dan altijd moet bedenken die persoon is gekozen en $\mathrm{ik}$ niet. Dus dat legt iets meer gewicht in de schaal. En om uiteindelijk die loyaliteit te hebben, dus dat je je eigen expertise in dienst stelt van de democratische rechtsstaat, dat is denk ik waar het voor mij persoonlijk op neer komt.'

'De minister is toch gewoon op de een of andere manier democratisch gelegitimeerd. Die gaat namens zijn partij en het volk en iedereen dingen doen en mijn taak is om hem zo goed en volledig mogelijk te adviseren zodat hij goede beslissingen kan nemen, dus ik schrijf gewoon op wat mij en dan vooral vanuit het juridische opvalt, wat ik denk dat goed is, wat ik denk dat minder goed is of wat risico in zich heeft, zodat hij alle gezichtspunten heeft.'

\section{Analyse en conclusie}

Dit onderzoek draaide om de vraag hoe wetgevingsjuristen omgaan met beleidsvoornemens die op juridische of rechtsstatelijke bezwaren stuiten en hoe zij in die gevallen hun rol rechtvaardigen. De aanleiding was gelegen in de kritiek van onder meer de Raad van State dat het 'denken over het recht binnen de overheid is gemarginaliseerd'. Wij vroegen ons af hoe wetgevingsjuristen zich staande houden binnen de smalle marges waarbinnen zij hun werk moeten doen. Bewegen zij mee of bieden zij tegenwicht?

\section{Spanning tussen beleid en recht niet gepercipieerd als een probleem}

Wat ons opviel in de vraaggesprekken met onze respondenten was dat zij de eerdergenoemde spanning tussen beleid en recht over het algemeen proberen te voorkomen of proberen weg te redeneren. In plaats van een tegenstelling op de spits te drijven, proberen de meeste wetgevingsjuristen, waar zij dat maar even kunnen, tegengestelde belangen te overbruggen. Dat doen zij doorgaans door actief mee te denken over de beleidsvraag (de probleemdefinitie) en mogelijke varianten. Zij leven zich, op basis van hun bestuurlijke en politieke sensitiviteit, in het beleid in en nemen de rol aan van beleidsmaker. Door in een vroegtijdig stadium van beleidsontwikkeling invloed uit te oefenen, komen zij in een later stadium bij het redigeren van de wettekst minder in de problemen. Deze rolopvatting sluit naadloos aan bij wat Van Lochem typeerde als de 'politieke adviseur'. Wij spraken ook een kleinere groep wetgevingsjuristen voor wie er zelfs helemaal geen tegenstelling leek te bestaan. Deze groep stelt zich zeer pragmatisch en 
flexibel op en weet naar eigen zeggen, mede op basis van hun vindingrijkheid en spitsvondigheid, altijd wel een oplossing te vinden in de vorm van een passende wettekst. We zien hierin de rolopvatting van de 'flexibele adviseur' van Van Lochem terug. Ook de door Mastenbroek en Peeters Weem geconstateerde ontwikkeling richting een 'pragmatische visie' op recht (in hun geval: het Europese recht) zien wij terug in onze interviews. Het komt volgens onze respondenten in de praktijk niet zo vaak voor dat wetgevingsjuristen zich geroepen voelen zich krachtig uit te spreken tegen omstreden wet- en regelgeving. En als zij dat al doen, laten zij hun negatieve advies meestal vergezeld gaan van enig alternatief.

\section{De wetgevingsjurist verschiet van kleur}

Uit ons onderzoek komt tevens naar voren dat het merendeel van de geïnterviewde wetgevingsjuristen bij voorkeur een constructief-kritische rol vervult. In hun wens effectief te blijven opereren, zijn zij opgeschoven richting beleid. Dit heeft evenwel tot gevolg dat het onderscheid tussen beleidsambtenaar en wetgevingsjurist dreigt te vervagen. Wij formuleren dit bewust voorzichtig, omdat ons onderzoek beperkt van omvang is en deze relatie bovendien louter vanuit het perspectief van de wetgevingsjuristen is bekeken. Het is nog maar de vraag of beleidsambtenaren zich kunnen vinden in de typering van wetgevingsjuristen als constructief-kritisch.

Het verlagen van de schotten tussen afdelingen binnen de ministeries heeft onmiskenbaar voordelen, niet in de laatste plaats een efficiënt wetgevingsproces. Er zijn echter ook nadelen. Het grootste risico is onzes inziens dat de instrumentalistische kijk op het recht, die eerder is geconstateerd ten aanzien van beleidsambtenaren, ${ }^{32}$ zich nog verder ontwikkelt. Als wetgevingsjuristen hun beperkte handelingsruimte minimalistisch invullen, door bijvoorbeeld alleen oog te hebben voor de ondergrenzen van wat juridisch haalbaar is of door de onbepaaldheid van het recht louter ten faveure van een beleidsvoornemen uit te leggen, kan de rechtsbeschermende functie van het recht op de achtergrond raken. Wij hebben hier in ons onderzoek enkele voorbeelden van gezien, bijvoorbeeld waar door wetgevingsjuristen werd benadrukt dat internationale mensenrechtenverdragen altijd wel ruimte bieden voor inperking van mensenrechten. Dat is een vorm van rechtsrelativisme waar Van Lochem al eerder voor waarschuwde.

\section{Articuleren beroepsethiek}

Indien de beroepsethiek van wetgevingsjuristen meer gearticuleerd zou worden, dan zouden wetgevingsjuristen waar nodig een beroep kunnen doen op deze normen in hun discussies met hun beleidscollega's. Ook kan het aan henzelf meer focus geven bij hun werkzaamheden. Het huidige normatieve kader (de ambtseed, de algemene gedragscode voor rijksambtenaren, de Aanwijzingen voor de regelgeving, het Integraal Afwegingskader) geeft onzes inziens onvoldoende houvast voor een kritische opstelling van wetgevingsjuristen. We hebben gezien dat een ambtenaar die zonder al te veel tegenspraak doet wat hem gevraagd wordt, zijn rol net zo gemakkelijk rechtvaardigt met een verwijzing naar de democratische 
rechtsstaat als een ambtenaar die zich juist heel principieel opstelt als bijvoorbeeld het legaliteitsbeginsel in het geding is. Wetgevingsjuristen worden geacht zich met alle mogelijke vragen rondom wetgeving bezig te houden, waaronder de wenselijkheid, handhaafbaarheid, de mogelijke alternatieven voor wetgeving en de mogelijke regeldruk die wetgeving oplevert. Hoezeer een integrale visie op wetgeving ook van belang is, de focus op het recht en beginselen van rechtsstatelijkheid dreigen daarmee ondergesneeuwd te raken.

Hoewel wetgevingsjuristen zelf geen redenen zien om hun beroepsethiek meer te articuleren, denken wij dat dit behulpzaam zou kunnen zijn bij het bepalen van hun opstelling of en hoe zij tegenspraak bieden. De functie van wetgevingsjurist zal dan duidelijk uit de verf komen. Wetgevingsjuristen zeggen wel duidelijke grenzen te trekken, maar het hangt overwegend van de persoon van de ambtenaar en van de situatie af of ze dat ook daadwerkelijk doen en of ze daarin slagen. Aan dit thema zou meer aandacht kunnen worden geschonken, zowel binnen de Academie voor Wetgevingsjuristen (waar al wel enige aandacht aan dit onderwerp wordt besteed) als binnen de reguliere Rechtenopleidingen, waar nog veel te weinig aandacht uitgaat naar wetgevingsjuristen en de totstandkoming van wetgeving. ${ }^{33}$

\section{Referenties}

Brenninkmeijer, A., 'Stresstest rechtsstaat Nederland', NJB 2015(16), p. 1046 e.v.

Gestel, R.A.J. van, 'Rol van de wetgevingsjurist: zwoegers in het vooronder of professionals in de frontlinie?', Regelmaat 2011(1), p. 3-6.

Hirsch Ballin, E., 'De rechtsstaat, wachten op een nieuwe dageraad?', NJB 2011-29(2), p. 71-73.

Hoekema, A., 'Onderhandelend bestuur', Recht der Werkelijkheid 1994(1), p. 97-114.

Huls, N. \& S. Stoter, 'Welke rol spelen ambtenaren achter de schermen van het wetgevingsproces?', in: M.L.M. Hertogh \& H.A.M. Weyers, Het recht van onderop, Nijmegen: Ars Aequi 2011, p. 19-40.

Kraan, K. \& B. Niemeijer, 'De opleiding tot overheidsjurist', Handelingen NJV, 148e jaargang, Deventer: Wolters Kluwer 2018, p. 93-128.

Lochem, P.J.P.M. van, De spanning tussen ambtelijke loyaliteit en correct overheidshandelen, Digitale publicatiereeks Recht en Overheid, Den Haag: Academie voor Wetgeving/Academie voor overheidsjuristen 2012.

Lochem, P.J.P.M. van, Rechtsrelativering: een verkenning op het terrein van het overheidshandelen (diss.), Den Haag: Boom Juridische uitgevers 2013.

Loth, M., 'De goede jurist. Over morele moed, onafhankelijkheid en een riskante omgeving', in: J. Kole \& D. de Ruyter (red.), Code en karakter. Beroepsethiek in onderwijs, jeugdzorg en recht, Amsterdam: SWP 2009, p. 113-126.

Mastenbroek, E., 'Guardians of EU law? Analysing roles and behaviour of Dutch legislative drafters involved in EU compliance', Journal of European Public Policy 2017(24), p. 1289-1307. 
Mastenbroek, E. \& T. Peeters Weem, In spagaat tussen Brussel en Den Haag? De Europeanisering van het wetgevingsvak, Nijmegen: Center for Policy Analysis, Radboud Universiteit Nijmegen 2009.

Mein, A.G., Tegenwicht of meebewegen? Over balanceren door professionals bij de toepassing van het recht (lectorale rede), Amsterdam: HvA Publicaties 2016.

Mein, A.G., 'U vraagt wij draaien? Veranderingen in de plaats en rol van de jurist binnen de gemeente', Gemeentestem 2019(7), p. 343-344.

Raad van State, Jaarverslag 2015, Den Haag: Raad van State 2016.

Raad van State, Jaarverslag 2018, Den Haag: Raad van State 2019.

Snellen, I.Th.M., Boeiend en geboeid. Ambivalenties en ambities in de bestuurskunde (oratie), Alphen aan de Rijn: Tjeenk Willink 1987.

Stoter, W.S.R. \& N.J.H. Huls, Onderhandelend wetgeven: een proces van geven en nemen, Den Haag: Sdu Uitgevers 2003.

Stout, H.D. \& A.J. Hoekema (red.), Onderhandelend Bestuur, Boekenreeks NJB 16, Zwolle: Tjeenk Willink 1994.

Tholen, B. \& E. Mastenbroek, 'Guardians of the Law or Loyal Administrators? Toward a Refined Administrative Ethos for Legislative Drafters', Administrative Theory \& Praxis 2013-35(4), p. 487-506.

Tjeenk Willink, H., Groter denken, kleiner doen. Een oproep. Amsterdam: Promotheus 2019.

Veerman, G.J., De wet als zinsbegoochelingstoestel. Over de kwaliteit van wetgeving (oratie), Maastricht: Universiteit Maastricht 2004.

Veerman, G.J., Belle en het Beest - over wetgeving en beleid, Digitale publicatiereeks Recht en Overheid, Den Haag: Academie voor Wetgeving/Academie voor overheidsjuristen 2011.

Veerman, G.J., Een empathische wetgever, meta-evaluatie van empirisch onderzoek naar de werking van wetten, Den Haag: Sdu Uitgevers 2013.

Verhey, L., 'Rechtswetenschap en wetgevingspraktijk. It takes two to tango', in: M. Abels (red.), Buitengewoon in dienst, een decennium wetgeving, liber amicorum aangeboden aan mr. G.N. Roes, Den Haag: Sdu Uitgevers 2007, p. 329-335.

Wierenga, W., De dynamiek van wens en recht. Een analyse van het werk van overheidsjuristen, Digitale publicatiereeks Recht en Overheid, Den Haag: Academie voor Wetgeving/Academie voor overheidsjuristen 2016. 